\title{
Wpływ leczenia operacyjnego na zmiany pamięci roboczej u chorych z procesami rozrostowymi w obrębie móżdżku - opis przypadków
}

\section{The impact of surgery on changes in the working memory of patients with hyperplastic lesions involving the cerebellum - case studies}

\author{
Marta Kęsik ${ }^{1 凶}$, Paweł Kawalec ${ }^{1}$, Dariusz Jeżewski1, Adam Koryzma² \\ ${ }^{1}$ Pomorski Uniwersytet Medyczny w Szczecinie, Zakład Neurokognitywistyki Stosowanej, ul. Unii Lubelskiej 1, 71-252 Szczecin \\ 2 Pomorski Uniwersytet Medyczny w Szczecinie, Zakład Diagnostyki Obrazowej i Radiologii Interwencyjnej, ul. Unii Lubelskiej 1, 71-252 Szczecin \\ marta_k@wp.pl
}

\begin{abstract}
Introduction: In the $19^{\text {th }}$ and $20^{\text {th }}$ centuries the cerebellum was mainly associated with human somato-motoric function, but later studies proved that its activity is much more complex. The cerebellum participates in the regulation of cognitive functions such as planning, verbal fluency, operational memory and abstract thinking.
\end{abstract}

\section{ABSTRAKT}

Wstęp: Móżdżek kojarzony był w XIX i XX w. głównie z funkcjami somatyczno-motorycznymi człowieka, jednak późniejsze badania dowiodły, że czynność jego jest znacznie bardziej złożona. Bierze on udział w regulacji funkcji poznawczych takich jak: planowanie, fluencja słowna, pamięć operacyjna czy myślenie abstrakcyjne. Opis przypadków: W pracy przedstawiono przypadki dwóch pacjentek z procesami rozrostowymi w obrębie móżdżku oraz
\end{abstract}

Case studies: We present the cases of two patients with cerebellar hyperplasia and a description of the functions of their working memory before and after neurosurgical treatment.

Conclusions: The results indicate positive changes in working memory in the patients after surgical treatment of tumours in this area, and confirm the significant role of the cerebellum in this regard. Keywords: cerebellum; working memory; cognitive function.

opis funkcjonowania w zakresie ich pamięci roboczej przed leczeniem neurochirurgicznym i po leczeniu.

Wnioski: Otrzymane wyniki wskazują na pozytywne zmiany $\mathrm{w}$ funkcjonowaniu pamięci roboczej u chorych po przebytym leczeniu operacyjnym guzów tej okolicy i potwierdzają znaczenie móżdżku.

Słowa kluczowe: móżdżek; pamięć operacyjna; funkcje poznawcze.

informacje nowe z tymi, które znajdują się w pamięci długotrwałej $[1,6]$.

Móżdżek kojarzony był w XIX i XX w. głównie z funkcjami somatyczno-motorycznymi człowieka, jednak później dowiedziono, że czynność jego jest znacznie bardziej złożona. Bierze on udział w regulacji funkcji poznawczych takich jak: planowanie, fluencja słowna, pamięć operacyjna czy myślenie abstrakcyjne [7]. Występowanie zaburzeń poznawczych u pacjentów z uszkodzeniem móżdżku jest szczególnie widoczne przy zmianach w tylnych częściach półkul móżdżku i robaku [8]. Schmahmann i Sherman doszli do wniosku, że chorzy z uszkodzeniami móżdżku obok objawów motorycznych przejawiają również złożone objawy poznawczo-emocjonalne [9]. Na opisanie owych objawów zaproponowali termin „móżdżkowy zespół poznawczo-emocjonalny” (cerebellar cognitive affective syndrome - CCAS). W Polsce badaniami nad CCAS u dzieci po resekcji guza móżdżku zajmowali się m.in. Maryniak i Roszkowski [10]. Również w Klinice Neurochirurgii i Neurochirurgii Dziecięcej oraz w Zakładzie Neurokognitywistyki Stosowanej Pomorskiego Uniwersytetu Medycznego w Szczecinie prowadzone są badania dotyczące modulacji móżdżkowej czynności kognitywnych.
3) notes wzrokowo-przestrzenny - przechowujący informacje wzrokowo-przestrzenne; 4) bufor epizodyczny - integrujący 

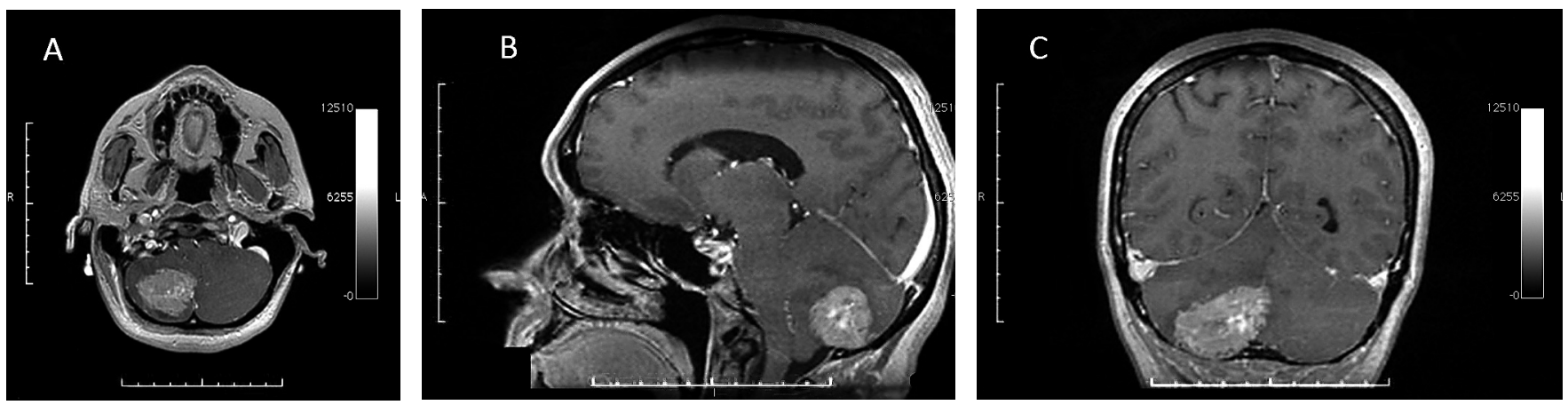

RYCINA 1. Pacjentka 1. Przedoperacyjne badanie NMR w obrazach T1 zależnych ze wzmocnieniem kontrastowym (A - poprzeczna; B - strzałkowa; C - wieńcowa) i z widocznym litym guzem prawej półkuli móżdżku

Udział móżdżku w funkcjonowaniu pamięci operacyjnej jest coraz szerzej opisywany w piśmiennictwie oraz potwierdzany w badaniach klinicznych $[11,12,13,14,15,16]$. Wykazano ujawniające się zaburzenia pamięci operacyjnej u pacjentów po udarach krwotocznych móżdżku, a także u chorych z guzami tej okolicy. Nadal pozostaje niejasna topografia czynnościowa móżdżku w tym zakresie.

\section{OPIS PRZYPADKÓW}

Przypadek 1. Kobieta 45-letnia z wykształceniem wyższym ekonomicznym, pracująca jako agentka celna, bez nałogów, prowadząca zdrowy i aktywny tryb życia. W 2014 r. u chorej rozpoznano złośliwy nowotwór obu piersi. W leczeniu zastosowano wówczas obustronną mastektomię oraz chemio- i radioterapię. Około 2 lata później u chorej z powodu utrzymujących się bólów głowy, nudności i wymiotów wdrożono diagnostykę neuroobrazową, uwidaczniając rozległy proces rozrostowy prawej półkuli móżdżku z towarzyszącym obrzękiem i efektem masy (ryc. 1). Poza podmiotowymi objawami nadciśnienia wewnątrzczaszkowego, które ustąpiły po wdrożonym leczeniu przeciwobrzękowym, badanie neurologicznie nie ujawniło innych objawów i deficytów. Podczas operacji całkowicie usunięto guz na drodze kraniotomii podpotylicznej prawostronnej.

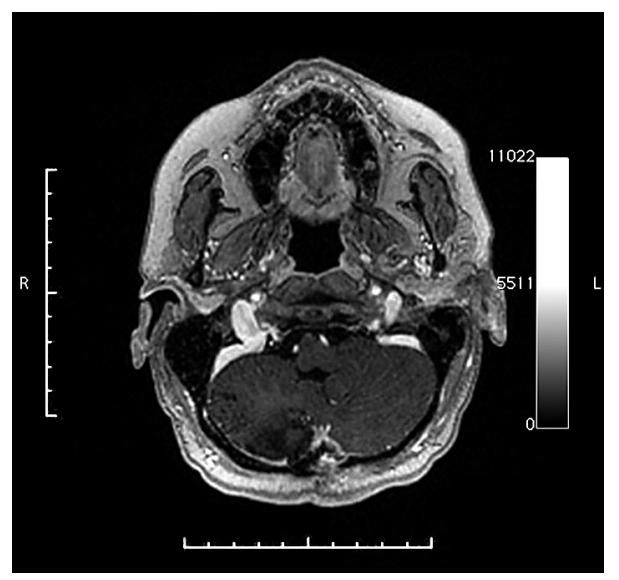

RYCINA 2. Pacjentka 1. Pooperacyjny poprzeczny skan NMR w obrazie T1 zależnym ze wzmocnieniem kontrastowym i z uwidocznioną lożą po całkowitej resekcji zmiany
Przebieg pooperacyjny był niepowikłany, a stan neurologiczny chorej po zabiegu nie uległ zmianie (ryc. 2). W badaniu histopatologicznym potwierdzono wtórny metastatyczny charakter zmiany i zakwalifikowano chorą do uzupełniającej radioterapii.

Stan psychologiczny. Pierwsze badanie psychologiczne wykonane w dniu poprzedzającym operację ukierunkowane było na ocenę poziomu funkcjonowania poznawczego i ujawniło występowanie u chorej trudności m.in. w zakresie pamięci operacyjnej, koncentracji uwagi, elastyczności poznawczej, pamięci wzrokowej i fluencji słownej. Pacjentka zgłaszała trudności związane z „uciekaniem myśli i niemożnością dostatecznego skupienia się na codziennych zadaniach". Podczas badania pacjentka była prawidłowo zorientowana auto- i allopsychicznie. W zakresie funkcjonowania behawioralno-emocjonalnego obserwowano obniżenie nastroju, nasilony lęk oraz zaburzenia kontroli uwagi.

Wykonane przez pacjentkę zadania, skierowane na ocenę poziomu funkcjonowania pamięci operacyjnej, ujawniły znaczne deficyty w tym zakresie. Zaobserwowano duże trudności w wykonaniu próby polegającej na seryjnym odejmowaniu cyfr. Otrzymany wynik ujawnił problemy z wykonywaniem operacji w pamięci oraz w zakresie kalkulii. Utrudnione było również utrzymanie informacji w pamięci, a także wykonanie na nich operacji polegających na odwrotnym powtórzeniu kolejności cyfr, liter i słów. Pojemność werbalnej pamięci bezpośredniej była u pacjentki znacznie ograniczona. Wynik testu łączenia punktów wykazał obniżenie sprawności pracy umysłowej, problemy z funkcjonowaniem wzrokowo-przestrzennej pamięci operacyjnej, koncentracją i przerzutnością uwagi oraz przełączaniem się na nowe kryterium po wyuczeniu jednej zasady reagowania. Chora miała trudności z operowaniem informacjami w pamięci, konieczne było bowiem cofanie się w celu przypominania poprawnej kolejności liter i cyfr. Uzyskane przez pacjentkę wyniki mogły wskazywać na trudności z utrzymaniem informacji w pamięci oraz wykonywaniem na nich operacji. Ponadto obok owych zaburzeń stwierdzono trudności z koncentracją i przerzutnością uwagi, które również mogły wpłynąć znacząco na uzyskane przez chorą wyniki.

Drugie badanie przeprowadzone po tygodniu od operacji ujawniło nieznaczną poprawę w zakresie funkcjonowania pamięci operacyjnej. W subiektywnej ocenie chora zgłaszała poprawę w zakresie skupienia uwagi. Zaobserwowano 
utrzymujące się trudności podczas seryjnego odejmowania, mimo to liczba poprawnych odpowiedzi była większa niż w badaniu wyjściowym. Pacjentka osiągnęła nieznacznie lepsze wyniki w zadaniach polegających na powtarzaniu cyfr, liter i słów w odwrotnej kolejności. Ilość powtórzonego materiału była również nieznacznie większa niż w badaniu przed operacją, a same zadania wykonane bez błędów. Otrzymane wyniki testu łączenia punktów nadal utrzymywały się w granicach niskich, mimo to zadanie zostało wykonane bez błędów oraz w krótszym czasie. Na podstawie otrzymanych wyników oraz obserwacji można było wnioskować o nieznacznej poprawie w zakresie funkcjonowania pamięci operacyjnej zarówno werbalnej, jak i wzrokowo-przestrzennej oraz w zakresie koncentracji uwagi.

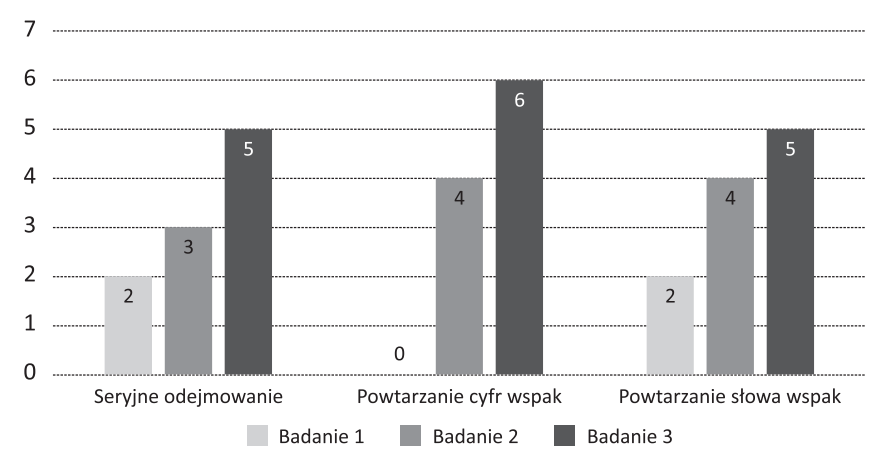

RYCINA 3. Pacjentka 1. Zmiany pojemności pamięci bezpośredniej (liczba elementów powtórzonych) oraz możliwości wykonywania operacji w pamięci podczas poszczególnych badań

Trzecie badanie psychologiczne odbyło się 2 miesiące po operacji. Otrzymane wyniki wskazywały na dalszą poprawę funkcjonowania pamięci operacyjnej oraz koncentracji uwagi w porównaniu do badania drugiego. Subiektywnie pacjentka opisywała mniejsze problemy z koncentracją oraz rzadsze zapominanie informacji w sytuacjach codziennych. Chora prawidłowo i sprawnie wykonała próby powtarzania liter i słów wspak, a także próbę seryjnego odejmowania. Powtarzanie cyfr wspak wykazało nieco większą pojemność pamięci bezpośredniej oraz sprawniejsze wykonywanie operacji w pamięci niż w badaniach wcześniejszych. Zaobserwowano poprawę funkcjonowania werbalnej pamięci operacyjnej. Test łączenia punktów został wykonany sprawniej i szybciej. Całość badań wskazała na dalszą poprawę sprawności pracy umysłowej, funkcjonowania werbalnej i wzrokowo-przestrzennej pamięci operacyjnej oraz koncentracji, przerzutności i podzielności uwagi (ryc. 3).

Przypadek 2. Kobieta 59-letnia z wykształceniem średnim chemicznym, pracująca jako laborantka w zakładach chemicznych, nałogowo paląca papierosy. Leczona z powodu raka lewej piersi, zgłosiła się z powodu zaburzeń chodu i równowagi. W badaniu tomografii komputerowej uwidoczniono rozległy proces rozrostowy lewej półkuli móżdżku z wtórnym wodogłowiem obturacyjnym (ryc. 4 i 5). Neurologicznie wykazano niewielki niedowład kończyn lewych ( $4 / 5 \mathrm{wg}$ Lovetta) oraz zaburzenia równowagi z dodatnią próbą Romberga. Z uwagi na obraną strategię leczenia choroby podstawowej i zaawansowany miejscowo proces zdecydowano o dwuetapowym zabiegu neurochirurgicznym. Po niepowikłanym leczeniu zastawką komorowo-otrzewnową wykonano mastektomię, a następnie kolejny zabieg neurochirurgiczny z radykalną resekcją guza. Stan ogólny i neurologiczny chorej po leczeniu nie uległ istotnej zmianie. W badaniu histopatologicznym potwierdzono wtórny metastatyczny charakter zmiany i zakwalifikowano chorą do uzupełniającej radioterapii.

Stan psychologiczny. Pierwsze badanie psychologiczne poprzedzające leczenie operacyjne ujawniło u chorej ogólne obniżenie sprawności funkcjonowania poznawczego. Obok zaburzeń pamięci operacyjnej zauważono również trudności w zakresie pamięci długotrwałej, przyswajania i wydobywania informacji po krótkim i długim odroczeniu, pamięci wzrokowej, fluencji słownej, koncentracji i przerzutności uwagi, funkcji wykonawczych oraz zdolności wzrokowo-przestrzennych. U pacjentki obserwowano też zaburzenia behawioralno-emocjonalne związane z osłabieniem kontroli uwagi, w tym utrudnione hamowanie reakcji i liczne perseweracje. Ujawniono również zaburzenia kontroli emocjonalnej z impulsywnością i labilnością emocjonalną, a także nieadekwatne reakcje społeczne przejawiające się zachowaniem opozycyjnym i niedostosowanym do sytuacji, z wyraźną irytacją. Podczas badania pacjentka była prawidłowo zorientowana auto- i allopsychicznie.

Zadania ukierunkowane na ocenę poziomu funkcjonowania pamięci operacyjnej ujawniły znaczne deficyty w tym zakresie. Chora nie była w stanie wykonać w pamięci operacji polegającej na seryjnym odejmowaniu, cofała się do początku działania; wystąpiły liczne perseweracje; wymagane było
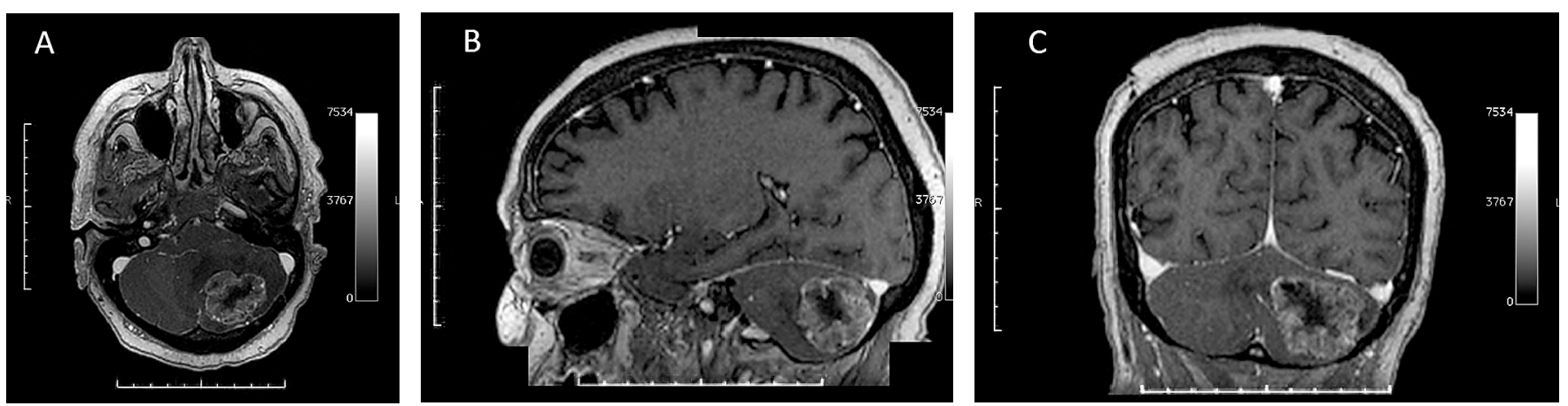

RYCINA 4. Pacjentka 2. Przedoperacyjne badanie NMR w obrazach T1 zależnych ze wzmocnieniem kontrastowym (A - poprzeczna; B - strzałkowa; C - wieńcowa) i z widocznym lito-torbielowatym guzem lewej półkuli móżdżku 


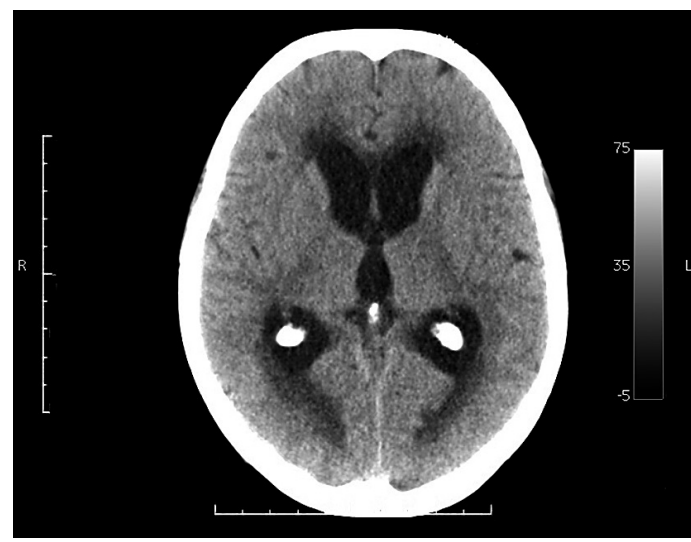

RYCINA 5. Pacjentka 2. Przedoperacyjny poprzeczny skan tomografii komputerowej z widocznym aktywnym wodogłowiem obturacyjnym

wielokrotne powtarzanie instrukcji. Obserwowano również trudności z inicjowaniem operacji i skupieniem uwagi. Zadania polegające na odwrotnym literowaniu słowa, wymienianiu miesięcy wspak oraz powtarzaniu cyfr wprost i wspak nie zostały wykonane poprawnie. Chora nie potrafiła wykonać zadań z powodu dużych trudności z utrzymaniem informacji w pamięci, niemożliwym było więc wykonanie na nich operacji. Obserwowano utrudnione przyswajanie i wydobywanie danych z pamięci oraz ograniczenie pojemności pamięci bezpośredniej. Wykonanie testu łączenia punktów ujawniło obniżenie sprawności pracy umysłowej, deficyty w zakresie wzrokowo-przestrzennej pamięci operacyjnej oraz procesów uwagowych. Chora uzyskała bardzo niskie wyniki, częściowo nie ukończyła zadania z powodu licznych błędów. Wystąpiły trudności ze skupieniem i przerzutnością uwagi oraz z utrzymaniem informacji w pamięci. Otrzymane wyniki wykonania prób, testów oraz dane z obserwacji mogą potwierdzać występowanie u chorej zaburzeń w zakresie funkcjonowania pamięci operacyjnej, które ograniczają możliwość utrzymania spójnego toku myślenia. Z kolei zaburzenia uwagi utrudniały chorej przyswajanie i odszukiwanie nowych informacji.

Drugie badanie psychologiczne wykonane tydzień po operacji wykazało nieznaczną poprawę w zakresie funkcjonowania pamięci operacyjnej, zaś występujące przed operacją zaburzenia behawioralno-emocjonalne przejawiane były w znacząco mniejszym nasileniu. W próbie seryjnego odejmowania chora uzyskała nieco lepszy wynik niż przed operacją, jednak nadal obserwowano trudności związane z koncentracją uwagi potrzebną do wykonania działań. Wyniki prób polegających na odwrotnym powtórzeniu kolejności cyfr, liter i słów były lepsze. Chora wykonała zadania poprawnie, zaś pojemność pamięci bezpośredniej była nieco większa. Test łączenia punktów także został wykonany lepiej niż przed operacją. W odniesieniu do norm ze względu na czas wykonania otrzymany wynik nadal utrzymywał się w niskich granicach, jednak zadanie zostało wykonane poprawnie i bez błędów. Otrzymany wynik może świadczyć o nieznacznej poprawie w zakresie funkcjonowania wzrokowo-przestrzennej pamięci operacyjnej, elastyczności poznawczej, a także koncentracji i przerzutności uwagi.

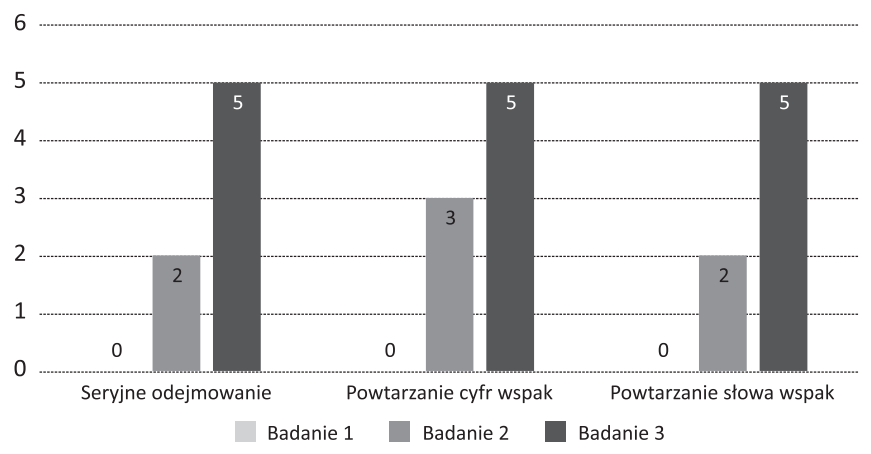

RYCINA 6. Pacjentka 2. Zmiany pojemności pamięci bezpośredniej (liczba elementów powtórzonych) oraz możliwości wykonywania operacji w pamięci podczas poszczególnych badań

Trzecie badanie psychologiczne przeprowadzone zostało 2 miesiące po operacji. Pacjentka odczuwała poprawę w zakresie pamięci, zgłaszała również rzadsze zapominanie bieżących informacji, a także mniejsze problemy z koncentracją uwagi przy wykonywaniu zadań codziennych. Chora prawidłowo i sprawnie wykonała próby powtarzania liter i słów wspak. Nieco wolniej, lecz bezbłędnie wykonana została próba seryjnego odejmowania. Powtarzanie cyfr wspak wykazało nieco większą pojemność pamięci bezpośredniej oraz sprawniejsze wykonywanie operacji w pamięci niż w badaniach wcześniejszych. Wyniki testu łączenia punktów również wykazały nieco sprawniejsze tempo pracy umysłowej oraz lepszy czas wykonania w porównaniu do badań wcześniejszych. Dane te mogą więc wskazywać na nieznaczną poprawę funkcjonowania w zakresie werbalnej i wzrokowo-przestrzennej pamięci operacyjnej, pojemności pamięci bezpośredniej oraz koncentracji, przerzutności i podzielności uwagi po usunięciu guza z lewej półkuli móżdżku (ryc. 6).

\section{DYSKUSJA}

Opisane przypadki dwóch pacjentek z uszkodzeniami w strukturach móżdżku obrazują występowanie zaburzeń procesów poznawczych, z których część jest charakterystyczna dla CCAS. W prezentowanych dwóch przypadkach przedstawiono i opisano proces zmian w funkcjonowaniu pamięci operacyjnej przed zabiegiem, a następnie w odstępie tygodnia oraz 2 miesięcy od operacji. Badania psychologiczne wykonane przed leczeniem ukierunkowane były na ocenę poziomu funkcjonowania poznawczego, głównie w zakresie pamięci operacyjnej, i ujawniły u pacjentek znaczne deficy ty w tym zakresie. U obydwu chorych przed operacją poziom funkcjonowania pamięci operacyjnej zarówno werbalnej, jak i wzrokowo-przestrzennej był na bardzo niskim poziomie.

Badania niektórych autorów dowodzą, iż uszkodzenia w strukturach móżdżku, głównie w tylnych częściach półkul oraz w robaku, wpływają na pogorszenie funkcjonowania poznawczego, w tym pamięci roboczej [7, 8]. Inne badania, które przeprowadzili Gottwald i wsp. [17], wykazały obecność 
zaburzeń pamięci operacyjnej i koncentracji uwagi u 21 pacjentów z udarem krwotocznym i guzami móżdżku. Spostrzeżenia własne są zgodne również z innymi doniesieniami naukowymi opisującymi związek pomiędzy uszkodzeniami w obrębie móżdżku a funkcjonowaniem pamięci operacyjnej $[12,16]$. U obu pacjentek przed zabiegiem operacyjnym widoczne było znaczne pogorszenie funkcjonowania pamięci operacyjnej zarówno werbalnej, jak i wzrokowo-przestrzennej, a także ograniczenie pojemności pamięci bezpośredniej. Niesprawność pamięci operacyjnej ogranicza możliwość utrzymania spójnego toku myślenia i prowadzi do zmącenia, szczególnie w złożonych sytuacjach wymagających równoczesnego brania pod uwagę kilku zmiennych. Zaburzenia uwagi utrudniają przyswajanie i odszukiwanie nowych informacji oraz prowadzą do wtórnych ubytków pamięci [18]. Objawy te z różnym nasileniem obserwowane były u obydwu pacjentek przed operacją. Po chirurgicznym usunięciu guza móżdżku obserwowana była poprawa w zakresie pamięci roboczej, jakkolwiek w różnym stopniu u obu chorych. Przytaczane wieloczynnikowe przyczyny zaburzeń reologicznych i elastancji tylnej jamy czaszkowej mogą być również podstawą spostrzeżeń innych autorów.

Kolejne badania psychologiczne w odstępie tygodnia oraz 2 miesięcy od operacji pozwoliły na zaobserwowanie nieznacznego zwiększenia pojemności pamięci bezpośredniej oraz poprawy funkcjonowania koncentracji, podzielności i przerzutności uwagi. Pojemność pamięci bezpośredniej była u pacjentek większa niż w badaniach wcześniejszych. Otrzymane wyniki mogą skłaniać ku stwierdzeniu, iż leczenie operacyjne guzów móżdżku może pozytywnie wpływać na funkcjonowanie pamięci roboczej u chorych.

Nadto na charakter otrzymanych wyników przed zabiegiem operacyjnym i po miały niewątpliwie wpływ wysoki poziom odczuwanego stresu przed operacją oraz sytuacja hospitalizacji, która powodowała u pacjentek wzmożone obawy o swój stan. Obydwie chore zgłaszały obniżenie samopoczucia oraz odczuwanie lęku i stresu związanego z myślami o operacji. Obecność wodogłowia obturacyjnego u pacjentki 2, a potencjalnie inicjowanego u pacjentki 1, mogła mieć wpływ na jakość wykonywanych zadań przed operacją.

Występowanie objawów poznawczych u pacjentów z uszkodzeniami móżdżku jest prawdopodobnie związane z uszkodzeniem połączeń pomiędzy móżdżkiem a korą przedczołową, korą płata potylicznego, skroniowego i korą układu limbicznego $[9,19,20]$. Proces wypierający, zwłaszcza w strukturalnie tak ograniczonym miejscu jak tylna jama czaszkowa, zawsze wywołuje następstwa naczynioruchowe, prowadzące do zmian funkcjonowania struktur odległych od uszkodzonego bezpośrednio miejsca. Trudno doszukiwać się jednoznaczności topograficznej w związku z konkretnym efektem wyższych czynności nerwowych. Jednak sumaryczny efekt patologiczny zmniejsza swe natężenie w przypadku poprawy objętościowo-ciśnieniowych warunków w następstwie zarówno usunięcia masy guza, jak i wykonania kraniotomii z natury rzeczy odbarczającej. Potwierdzają to obserwacje własne w zakresie pamięci roboczej, poczynione u chorych po zabiegu neurochirurgicznym.

\section{WNIOSKI}

Pozytywne zmiany w funkcjonowaniu pamięci roboczej u pacjentek po zabiegu neurochirurgicznym w obrębie móżdżku wydają się potwierdzać tezę o znaczącej jego roli w regulacji owej funkcji. Szczególnie uzasadnia ten wniosek poprawa pamięci po usunięciu ogniska uszkodzenia.

\section{PIŚMIENNICTWO}

1. Pąchalska M. Neuropsychologia kliniczna. Urazy mózgu. Warszawa: Wydawnictwo Naukowe PWN; 2014. p. 314-37.

2. Baddeley A. Working memory. New York: Oxford University Press; 1986. p. 25-30.

3. Borkowska A. Neuropsychologiczne i neurobiologiczne aspekty pamięci operacyjnej. Neuropsychiatr Neuropsychol 2006;1(1):31-42.

4. Awh E, Jonides J, Smith EE, Schumacher RA, Katz S. Dissociation of storage and rehearsal in verbal working memory. Psychol Sci 1996;7:25-31.

5. Jonides J, Smith EE, Koeppe RA, Awh E, Minoshima S, Mintun MA. Spatial memory in humans as revealed by PET. Nature 1993;363(6430):623-5. doi: $10.1038 / 363623 a 0$.

6. Baddeley A. The episodic buffer: a new component of working memory? Trends Cogn Sci 2000;4(11):417-23.

7. Ravizza SM, McCormick CA, SchlerfJE, Justus T, Ivry RB, Fiez JA. Cerebellar damage produces selective deficits in verbal working memory. Brain 2006;129:306-20. doi: 10.1093/brain/awh685.

8. Tavano A, Grasso R, Gagliardi C, Triulzi F, Bresolin N, Fabbro F, et al: Disorders of cognitive and affective development in cerebellar malformations. Brain 2007;130:2646-60. doi: 10.1093/brain/awm201.

9. Schmahmann JD, Sherman JC. The cerebellar cognitive affective syndrome. Brain 1998;121:561-79.

10. Maryniak A, Roszkowski M. Zespół poznawczo-emocjonalny u dzieci po resekcji łagodnych guzów móżdżku. Neurol Neurochir Pol 2005;39:202-6.

11. Marvel CL, Faulkner ML, Strain EC, Mintzer MZ, Desmond JE. An fMRI investigation of cerebellar function during verbal working memory in methadone maintenance patient. Cerebellum 2012;11(1):300-10. doi: 10.1007/s12311-011-0311-0.

12. Misciagna S, Iuvone L, Mariotti P, Silveri MC. Verbal short-term memory and cerebellum: evidence from a patient with congenital cerebellar vermis hypoplasia. Neurocase 2010;16(2):119-24. doi: 10.1080/13554790903329158.

13. Kirschen MP, Davis-Ratner MS, Milner MW, Chen A, Schraedley-Desmond P, Fisher PG, et al. Verbal memory impairments in children after cerebellar tumor resection. Behav Neurol 2008;20(1-2):39-53. doi: 10.3233/ BEN-2008-0216.

14. Pope PA, Miall RC. Task-specific facilitation of cognition by cathodal transcranial direct current stimulation of the cerebellum. Brain Stimul 2012;5(2):84-94. doi: 10.1016/j.brs.2012.03.006.

15. Thürling M, Hautzel H, Küper M, Stefanescu MR, Maderwald S, Ladd M.E, et al. Involvement of the cerebellar cortex and nuclei in verbal and visuospatial working memory: a 7 T fMRI study. Neuroimage 2012;62(3):153750. doi: 10.1016/j.neuroimage.2012.05.037.

16. Ding H, Qin W, Jiang T, Zhang Y, Yu C. Volumetric variation in subregions of the cerebellum correlates with working memory performance. Neurosci Lett 2012;508(1):47-51. doi: 10.1016/j.neulet.2011.12.016.

17. Gottwald B, Mihajlovic Z, Wilde B, Mehdorn HM. Does the cerebellum contribute to specific aspects of attention? Neuropsychologia 2003; 41(11):1452-60.

18. Bartczak E, Marcinowicz E, Kochanowski J. Zaburzenia funkcji poznawczych w udarze móżdżku a skrzyżowana diaschiza - opis przypadku. Aktual Neurol 2011;11(1):18-22.

19. Collinson SL, Anthonisz B, Courtenay D, Winter C. Frontal executive impairment associated with paraneoplastic cerebellar degeneration: a case study. Neurocase 2006;12(6):350-4. doi: 10.1080/13554790601076697.

20. Drepper J, Timmann D, Kolb FP, Diener HC. Non-motor associative learning in patients with isolated degenerative cerebellar disease. Brain 1999;122:87-97. 